\title{
Ammonium uptake and regeneration rates in a coastal upwelling regime
}

\author{
Mary-Lynn Dickson ${ }^{1,2}$, Patricia A. Wheeler ${ }^{1}$ \\ ${ }^{1}$ College of Oceanic and Atmospheric Sciences, Oregon State University, Corvallis, Oregon 97331-5503, USA \\ ${ }^{2}$ Graduate School of Oceanography, University of Rhode Island, Narragansett, Rhode Island 02882-1197, USA
}

\begin{abstract}
Ammonium uptake and regeneration rates were measured in time course experiments with ${ }^{15} \mathrm{~N}$ as a tracer. Both ammonium uptake and regeneration rates measured over 12 to $18 \mathrm{~h}$ remained essentially constant. However, as the length of the incubations increased the amount of usable data decreased dramatically due to substrate depletion and recycling of ${ }^{15} \mathrm{~N}$. Mass balance calculations indicated that 22 to $51 \%$ of the ammonium removed from the dissolved pool was not recovered in the particulate fraction. This appeared to be a more serious problem at 0 and $8 \mathrm{~m} \mathrm{(47 \% )} \mathrm{than} \mathrm{at} 25 \mathrm{~m}(22 \%)$. As a result, ammonium uptake rates were probably underestimated. At 0,12 , and $20 \mathrm{~m}$ uptake rates either balanced or exceeded regeneration rates, while at 8 and $25 \mathrm{~m}$ net regeneration occurred. The fastest rates were measured during upwelling-induced phytoplankton blooms, intermediate rates characterized post-bloom conditions and the lowest rates coincided with an active upwelling event. Ammonium uptake rates were highest durng the upwelling season (11 to $17 \mathrm{mmol} \mathrm{N} \mathrm{m} \mathrm{N}^{-2} \mathrm{~d}^{-1}$ ) and lowest during the non-upwelling season $\left(3 \mathrm{mmol} \mathrm{N} \mathrm{m}^{-2} \mathrm{~d}^{-1}\right)$, whereas regeneration rates did not differ significantly between seasons (11 to $20 \mathrm{mmol} \mathrm{N} \mathrm{m}^{-2} \mathrm{~d}^{-1}$ ).
\end{abstract}

KEY WORDS: Ammonium uptake Ammonium regeneration Coastal upwelling

\section{INTRODUCTION}

Early studies of upwelling systems concentrated on the utilization of nitrate by phytoplankton, even though there was evidence of high levels of grazing activity (Menzel 1967). Recognizing that phytoplankton assimilated different nitrogen sources, Dugdale \& Goering (1967) proposed the concept of 'new' and 'regenerated' primary production. They defined new production as primary production dependent on nitrogen sources introduced from outside the euphotic zone and made available to the phytoplankton via advection or diffusion of water from depth or from atmospheric and terrestrial inputs. Regenerated production is based on the assimilation of ammonium and/or urea produced within the water column as a result of grazing by micro- and macrozooplankton or the remineralization of organic matter by bacteria. Eppley \& Peterson's review (1979) showed that 50 to $90 \%$ of autotrophic production in oceanic, as well as coastal, ecosystems is supported by regenerated nitrogen.
The rate at which nitrogen is recycled in the euphotic zone is especially impressive when one considers that ambient ammonium and urea concentrations usually only contribute a few percent to the dissolved nitrogen pool. In order for reduced nitrogen to be available to the phytoplankton, it is implicit that organic nitrogen is turned over rapidly. Ammonium and urea turnover times are typically less than a day, and often have been measured to be on the order of hours (Glibert 1982, Paasche \& Kristiansen 1982, Harrison et al. 1983, 1985, Kokkinakis \& Wheeler 1988).

Early efforts to quantify ammonium regeneration rates stressed the importance of larger organisms in nutrient recycling (Harris 1959), even though the role of smaller organisms was the subject of speculation (Johannes 1964). With the development of isotope dilution methods (Harrison 1978, Caperon et al. 1979) and recognition of the importance of the microbial loop (Azam et al. 1983) the role of the microbial community as a source of nutrients was realized. It is now generally accepted that most ammonium regeneration is 
carried out by organisms less than $100 \mu \mathrm{m}$ in size (Harrison 1980, 1992). Size-fractionation studies by Glibert (1982) and by Probyn (1987) have clearly demonstrated that most (i.e. $>95 \%$ ) ammonium is produced by the $<15 \mu \mathrm{m}$ size class. Although bacteria and nanoflagellates dominate that particular size class, it is not yet clear whether bacteria are mainly producers (Harrison et al. 1983) or consumers (Wheeler \& Kirchman 1986) of ammonium, or what conditions favour one role over the other (Goldman et al. 1987).

Ammonium regeneration in coastal environments is fast, compared to offshore waters (Harrison 1978), due to high concentrations of biomass and high levels of primary production. The site chosen for this study was situated on the Newport hydrographic line in the Oregon (USA) upwelling zone. The local hydrography and upwelling circulation of this area have been extensively studied (e.g. Halpern 1976, Huyer 1976), but less is known about the biological response to upwelling events (e.g. Wroblewski 1977, Peterson et al. 1979 , Small \& Menzies 1981). The results presented in this paper represent one aspect of a larger study undertaken to quantify the nitrogen dynamics of this ecosystem (Dickson 1994). Since very little information is available on temporal variations, the objective of this study was to measure ammonium uptake and regeneration rates in time course experiments during upwelling and non-upwelling conditions. We critically examine the rate measurements to address 3 questions: Do rates depend on the length of the incubation period? Do rates vary with stage of upwelling? Do rates differ between upwelling and non-upwelling seasons?

\section{MATERIALS AND METHODS}

Sampling. A site $8 \mathrm{~km}$ off the Oregon coast $\left(44^{\circ} 40^{\prime} \mathrm{N}\right.$, $\left.124^{\circ} 40^{\prime} \mathrm{W}\right)$ was sampled from July 21, 1990 until August 20, 1991 (Day 205 to 597, where Day 1 is January 1, 1990) encompassing 12 experiments. The water depth was $70 \mathrm{~m}$. During the upwelling season (May through October) sampling was carried out every 2 wk. Winter sampling was conducted on a monthly basis when weather permitted.

Water was collected between 08:00 and 09:00 h from 3 depths $(0,8 \mathrm{~m}$ and either 12, 20, or $25 \mathrm{~m})$ with $5 \mathrm{l}$ Niskin bottles. It was immediately placed in acidwashed polypropylene carboys and transported to shore in shaded containers filled with surface seawater to keep the carboys at ambient temperature. All experimental work was carried out at the Hatfield Marine Science Center, Oregon State University, Newport. Once on shore, the water was mixed by gently inverting the carboys a number of times before samples were drawn.
Biomass and nutrient concentrations. Particulate organic nitrogen (PN) concentrations were determined by filtering 500 to $1000 \mathrm{ml}$ of seawater onto a combusted $25 \mathrm{~mm}$ Whatman GF/F filter, freezing the filter and then drying it at $60^{\circ} \mathrm{C}$ for $24 \mathrm{~h}$. A persulfate digestion converted the $\mathrm{PN}$ to $\mathrm{NO}_{3}^{-}$, which was then measured with a Technicon II AutoAnalyzer (Grasshoff et al. 1983) following the protocols of Whitledge et al. (1986).

Ammonium concentrations were measured manually in triplicate using the phenolhypochlorite method (Solórzano 1969). Concentrations were measured initially for each depth and then at each time point in triplicate.

Ammonium uptake and regeneration experiments. The water used in the uptake and regeneration experiments was held at ambient sea surface temperatures for approximately $2 \mathrm{~h}$ in covered $10 \mathrm{l}$ carboys before the start of an experiment and was not screened to remove large grazers. A $0.1 \mu \mathrm{M}$ addition (final concentration), or at times one that was $-10 \%$ of the ambient concentration, of $\left({ }^{15} \mathrm{NH}_{4}\right)_{2} \mathrm{SO}_{4}$ (99.0 atom\%, MSD Isotopes) was added to water from each depth in 4.51 Nalgene polycarbonate bottles. Once spiked with label, the bottles were placed in an environmental chamber simulating ambient seawater temperatures $\left(8\right.$ to $\left.10^{\circ} \mathrm{C}\right)$ and saturating light conditions $(-500 \mu \mathrm{E}$ $\mathrm{m}^{-2} \mathrm{~s}^{-1}$. Bottles from the lower 2 depths were placed in bags made of neutral density screening to simulate in situ light levels. Uptake and regeneration time course experiments were run simultaneously on water from 3 depths $(0$ and $8 \mathrm{~m}$ for all 12 experiments, $12 \mathrm{~m}$ from Day 205 to 233 for 3 experiments, $20 \mathrm{~m}$ on day 248 , and $25 \mathrm{~m}$ for the remaining 8 experiments) and consisted of 4 time points $(0.1,1$ to 3,4 to 8 , and 10 to $18 \mathrm{~h})$. At the end of the incubations samples were filtered under low vacuum pressure (<180 mm Hg) onto combusted $47 \mathrm{~mm}$ Whatman GF/F filters. Comparison of ammonium concentrations in filtered and unfiltered samples indicated that the filtration procedure did not enhance ammonium release. The filters were frozen and then dried at $60^{\circ} \mathrm{C}$ for $24 \mathrm{~h}$.

A modification of the protocol of Selmer \& Sörenssen (1986) was used to measure the dilution of ${ }^{15} \mathrm{NH}_{4}{ }^{+}$with ${ }^{14} \mathrm{NH}_{4}{ }^{+}$. A brief description of the solid phase extraction method for aqueous ${ }^{15} \mathrm{NH}_{4}^{+}$follows. Approximately $1 \mathrm{l}$ of filtrate was collected from each of the 3 depths at each time point. Of this, $900 \mathrm{ml}$ was dispensed into 1 l Nalgene polyethylene bottles that had been acid washed and thoroughly rinsed with distilled/ deionized water and a portion of the filtrate. Into the filtrate were added $6.3 \mathrm{ml}$ of phenol reagent $110 \mathrm{~g}$ phenol dissolved in $100 \mathrm{ml} 95 \% \mathrm{EtOH}, 6.3 \mathrm{ml}$ of sodium aquopentacyanoferrate $(\mathrm{AqF})$ reagent $(0.03 \mathrm{~g}$ AqF dissolved in $250 \mathrm{ml}$ of deionized/distilled water) 
and $31.5 \mathrm{ml}$ of oxidizing reagent $(1.6 \mathrm{ml} 5.5 \%$ sodium hypochlorite solution in $50 \mathrm{ml}$ of $0.25 \mathrm{M} \mathrm{NaOH}$ ). An addition of $100 \mu \mathrm{l}$ of 5.0 atom $\%{ }^{15} \mathrm{NH}_{4}$ carrier from a $0.04 \mu \mathrm{M} \mathrm{NH}_{4}{ }^{+}-\mathrm{N}$ solution was added to each bottle of filtrate plus reagents. Samples were placed in the dark for 15 to $25 \mathrm{~h}$ to allow complete indophenol formation. In addition, a carrier blank was processed for each depth. Once colour development was complete, samples were acidified to a $\mathrm{pH}$ of 6.30 with $1.0 \mathrm{M} \mathrm{H}_{3} \mathrm{PO}_{4}$ and split into duplicates. The indophenol red (containing the aqueous ${ }^{15} \mathrm{NH}_{4}$ ) was collected on $6 \mathrm{ml} \mathrm{C}_{18}$ extraction columns (J. T. Baker) that were conditioned with rinses of HPLC grade methanol and deionized/ distilled water. Impurities were removed from the indophenol red on the sorbent with a $2.5 \%$ methanol rinse (the rinse solution was adjusted to $\mathrm{pH} 10.0$ with a $0.25 \mathrm{M} \mathrm{NaOH}$ solution). The indophenol red was removed from the sorbent with $2 \mathrm{ml}$ of HPLC grade acetone and collected in glass vials. The volume of the solution in the vials was reduced to $\sim 200 \mu$ l by heating in a vacuum oven at 55 to $60^{\circ} \mathrm{C}$. At this point the solution was a 2-phase mixture. When the desired volume was obtained, $200 \mu \mathrm{l}$ of HPLC grade acetone was added to remove any dried material from the wall of the vial and to transform the 2-phase mixture into a homogeneous solution. The indophenol red extract was pipetted onto a precombusted $47 \mathrm{~mm}$ Whatman $\mathrm{GF} / \mathrm{F}$ glass fiber filter and dried in a vacuum oven at $80^{\circ} \mathrm{C}$ for at least $12 \mathrm{~h}$. This method of extracting aqueous ${ }^{15} \mathrm{NH}_{4}{ }^{+}$has a recovery rate of $75 \pm 16 \%$ (Wheeler \& Kokkinakis 1990)

Dried filters from the uptake experiments and the solid phase extractions were prepared for emission spectrometry following the micro-Dumas dry combustion method of LaRoche (1983) and analyzed for ${ }^{15} \mathrm{~N}$ with a Jasco N-150 emission spectrometer (Fielder \& Proksch 1975).

Calculations. The data from uptake and regeneration experiments were screened for violations of assumptions required for valid calculation of uptake rates. Data were excluded when ammonium concentrations were at or below the detection limit $(\leq 0.03 \mu \mathrm{M})$, and when ${ }^{15} \mathrm{~N}$ in the particulate material decreased from the previous time point (Dickson 1994). After the screening, the data set we used contained 71 uptake rate measurements and 42 regeneration rate measurements.

The equations of Dugdale \& Goering (1967) were used to calculate PN-specific $(V)$ and absolute $(\rho)$ hourly uptake rates. Ammonium uptake rates $(\rho)$ were corrected for isotope dilution. Daily ammonium uptake rates were calculated by adding together estimated light and dark uptake rates. Light ammonium uptake rates were calculated by multiplying the mean hourly uptake rate (obtained from the time course experi- ments) by the length of the photoperiod. Dark ammonium uptake rates were assumed to be $52 \%$ of the uptake in the light (Price et al. 1985, Wheeler et al. 1989).

Ammonium regeneration rates were calculated using either the equations of Blackburn (1979) and Caperon et al. (1979) or Glibert et al. (1982). The Blackburn/ Caperon method involves calculating the ammonium regeneration rate using the rate of change in the ammonium concentration and the relative abundance of ${ }^{15} \mathrm{NH}_{4}$. The Glibert et al. equations use the mean ammonium concentration and the change in the ${ }^{15} \mathrm{~N}$ content of the $\mathrm{NH}_{4}{ }^{+}$to calculate regeneration rates and were used when no change was observed in the ammonium concentration between time points. Mean hourly regeneration rates obtained from the time course experiments were multiplied by $24 \mathrm{~h}$ to calculate daily regeneration rates

Mass balance calculations were done to compare the amount of ${ }^{15} \mathrm{NH}_{4}{ }^{+}$removed from the dissolved pool with the amount of ${ }^{15} \mathrm{~N}$ measured in the PN fraction (Laws 1984). It was possible to calculate the amount of ${ }^{15} \mathrm{~N}$ in the dissolved ammonium pool at each time point by multiplying the measured isotopic enrichment of the ammonium by its concentration. Similarly, the ${ }^{15} \mathrm{~N}$ content of the PN fraction was estimated by multiplying the $\mathrm{PN}$ concentration by its measured atom $\%{ }^{15} \mathrm{~N}$ excess. The difference between the amount of labelled ammonium removed from the dissolved pool and that measured in the PN fraction was considered to be 'missing ${ }^{15} \mathrm{~N}$ ' and is reported as a percentage of the initial amount of added label.

Annual ammonium uptake and regeneration rates were estimated by integrating mean daily rates with respect to depth by the trapezoid-rule method. The mean of the integrated daily uptake and regeneration rates for the upwelling and the non-upwelling seasons were multiplied by the number of days in each season (i.e. upwelling season $=183 \mathrm{~d}$, non-upwelling season $=$ 182 d) and summed to give an annual rate. The variability associated with the annual ammonium uptake and regeneration rates was calculated from the standard deviations of the mean upwelling and nonupwelling data using the propagation of error method (Press et al. 1989).

Upwelling status. Criteria that were used to characterize the biological response to upwelling conditions encountered during sampling have been presented in Dickson (1994) and Dickson \& Wheeler (1995). Briefly, we used data obtained from CTD casts, as well as surface nitrate and cholorophyll a ( $\mathrm{chl}$ a) concentrations to define the upwelling status. High nitrate and low chl a concentrations on Days 191 (Jul 10, 1990) and 555 (Jul 9.1991) indicated active upwelling events. Upwellinginduced phytoplankton blooms were marked by ex- 
tremely high chl a and moderate nitrate concentrations and were sampled on Days 205 (Jul 24, 1990), 219 (Aug 7, 1990), 284 (Oct 11, 1990), and 569 (Jul 23, 1991). On Day 597 (Aug 20, 1991) high chl a and low nitrate concentrations suggested that this phytoplankton bloom had recently depleted surface nitrate. Postbloom conditions had extremely low $(<1 \mu \mathrm{M})$ nitrate and low chl a concentrations and were sampled on Days 233 (Aug 21, 1990), 248 (Sep 5, 1990), 501 (May 16, 1991), and 541 (Jun 25, 1991).

\section{RESULTS}

\section{Time course experiments}

Changes observed in the isotopic composition of the $\mathrm{PN}$ and the dissolved $\mathrm{NH}_{4}{ }^{+}$pool during a typical time course experiment are shown in Fig. 1. These results were fairly representative of those obtained from the other experiments. Over the first $7 \mathrm{~h}$ of the time course the PN became increasingly labelled with ${ }^{15} \mathrm{~N}$ (Fig. 1A), although by $12 \mathrm{~h}$ there was significant recycling of the label. Throughout the time course experiments the specific activity of the ammonium pool decreased (Fig. 1B). Ammonium concentrations in the incubation bottles
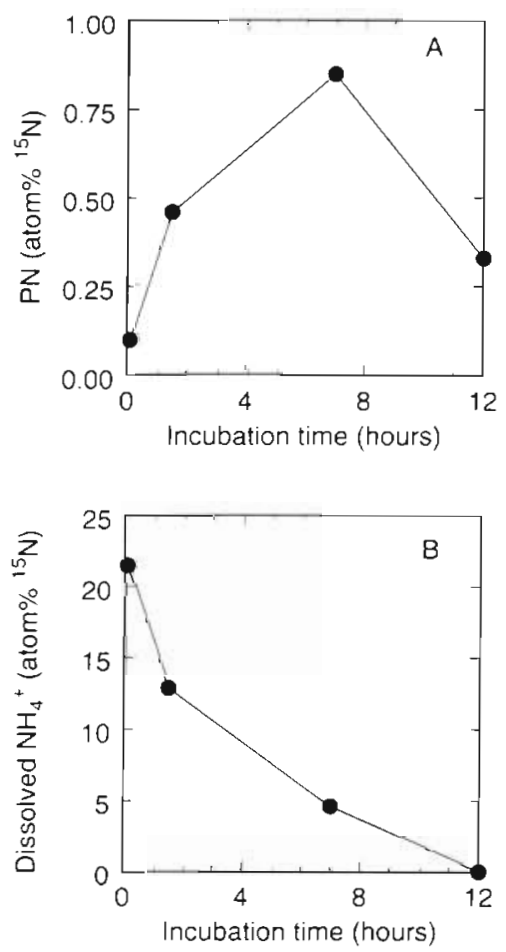

Fig. 1 Time course experiment showing the isotopic composition of (A) the particulate nitrogen fraction and (B) dissolved ammonium pool throughout the incubation period on Day 219 at $12 \mathrm{~m}$ decreased in 21 of the 26 experiments at a mean rate of $0.047 \mu \mathrm{M} \mathrm{h}^{-1}$ with a range from 0.006 to $0.167 \mu \mathrm{M} \mathrm{h}^{-1}$. In 2 experiments there was a net increase in ammonium concentration at a mean rate of $0.048 \mu \mathrm{M} \mathrm{h}^{-1}$, and in 3 experiments there was no net change in the ammonium concentration.

Time course changes in ammonium uptake and regeneration rates were evaluated by regressing the calculated rates against the incubation time (Fig. 2). The mean rate of change for ammonium uptake was $-0.52 \mathrm{nM} \mathrm{h}^{-2}$ (Fig. 2A), which is very small compared to the mean uptake rate of $36 \mathrm{nM} \mathrm{h}^{-1}$. Similarly, the mean rate of change for ammonium regeneration was $0.14 \mathrm{nM}$ $\mathrm{h}^{-2}$ (Fig. 2B), which is small compared to the mean regeneration rate of $38 \mathrm{nM} \mathrm{h}^{-1}$. From these experiments we conclude that uptake and regeneration rates were essentially constant over time. However, it should be noted that as the incubation period increased some of the data were excluded from the analysis due to depletion of ammonium and recycling of the ${ }^{15} \mathrm{~N}$. To illustrate this point the percentage of usable data in the uptake
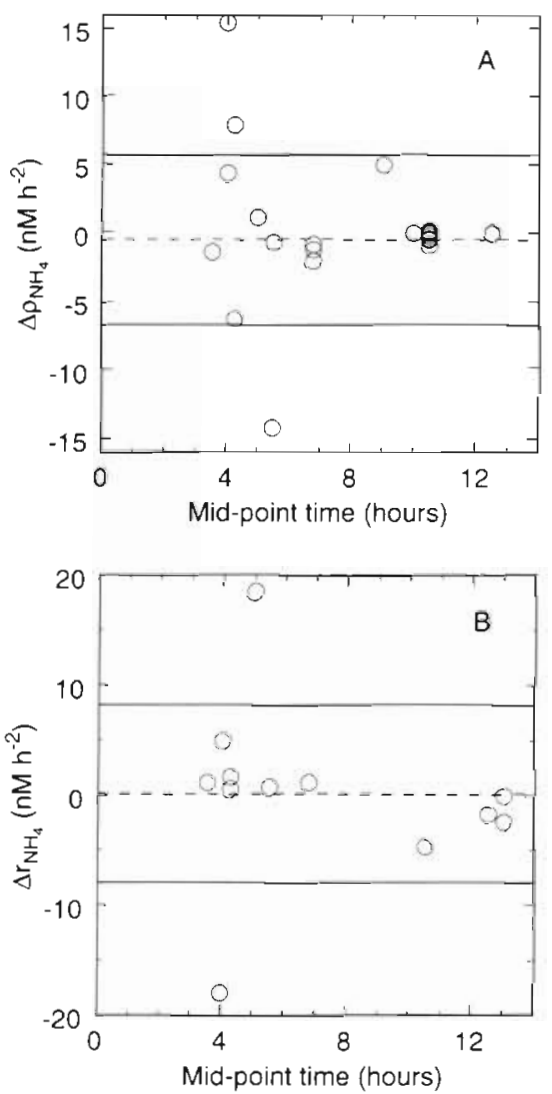

Fig. 2. Regression slopes from (A) ammonium uptake $\left(\Delta \rho_{\mathrm{NH}_{4}}\right)$ and $(B)$ regeneration time course $\left(\Delta r_{\mathrm{NH}_{4}}\right)$ experiments plotted against the mid-point incubation time for each experiment. The dashed horizontal lines indicate the mean rate of change, while the solid horizontal lines are \pm 1 SD. Mean $\Delta p_{\mathrm{NH}_{4}}=-0.52 \pm$ $6.21 \mathrm{nM} \mathrm{h}^{-2}, \mathrm{n}=24$ and mean $\Delta r_{\mathrm{NH}_{4}}=0.14 \pm 8.11 \mathrm{nM} \mathrm{h}^{-2}, \mathrm{n}=12$ 


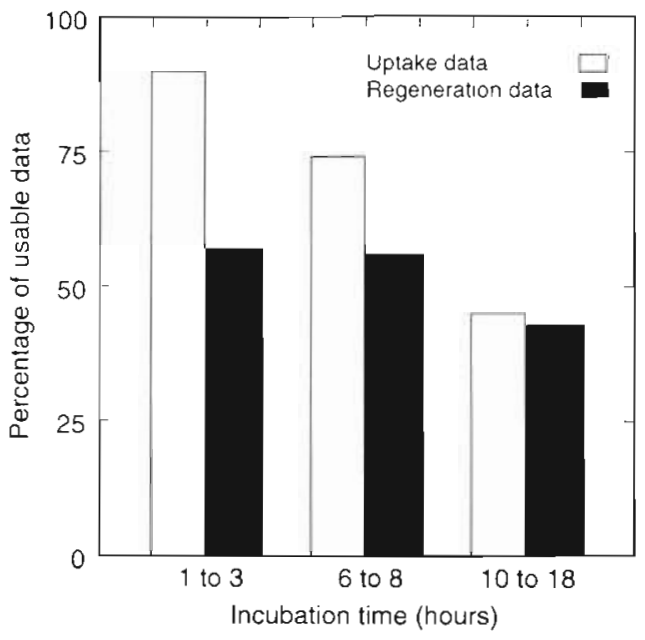

Fig. 3. Percentage of usable data as a function of incubation time for ammonium uptake and regeneration experiments. Sample numbers were: 1 to $3 \mathrm{~h}=30,6$ to $8 \mathrm{~h}=36,10$ to $18 \mathrm{~h}=42$

and regeneration rate experiments is plotted as a function of time (Fig. 3). In the uptake experiments, $90 \%$ of the data from the 1 to $3 \mathrm{~h}$ incubations but only $45 \%$ of the data from the 10 to $18 \mathrm{~h}$ incubations met the required assumptions of the ${ }^{15} \mathrm{~N}$ method (i.e. no substrate depletion or decrease measured in the ${ }^{15} \mathrm{~N}$ enrichment of the PN). Similarly in the regeneration experiments, the percentage of usable data decreased from 57 to $43 \%$ for the 1 to $3 \mathrm{~h}$ and 10 to $18 \mathrm{~h}$ incubations

Dilution of the dissolved ${ }^{15} \mathrm{NH}_{4}{ }^{+}$pool was significant over the duration of the time course experiments. The magnitude of isotope dilution is usually expressed by comparing the corrected uptake rate $(P)$ to the uncorrected rate $(\rho)$. For 1 to $3 \mathrm{~h}$ incubations isotope dilution only resulted in uptake rates being underestimated by $7 \%$ (Fig. 4). As the length of the incubations increased, so to did the correction for isotope dilution. For 6 to $8 \mathrm{~h}$ incubations there was a 2.5 -fold increase in uptake rates after correction for isotope dilution, while for 10 to $18 \mathrm{~h}$ experiments uptake rates increased by 5.5 -fold. Clearly, in coastal waters accurate determination of ammonium uptake rates must include a correction for isotope dilution even for incubations as short as $6 \mathrm{~h}$.

Mass balance calculations showed that, overall, $36 \%$ of the ${ }^{15} \mathrm{NH}_{4}{ }^{+}$removed from the dissolved pool was not recovered in the PN fraction (Table 1). In the upper $12 \mathrm{~m}$ of the water column the percentage of missing nitrogen ranged from 34 to $51 \%$ and did not appear to vary significantly among those depths. At $20 \mathrm{~m}$ all the initial label was recovered in the dissolved $\mathrm{NH}_{4}{ }^{+}$and PN fractions, but since only 1 experiment was conducted at that depth we hesitate to draw a general conclusion. At $25 \mathrm{~m}$, only $22 \%$ of the ammonium was missing at the end of the incubations. This is signifi-

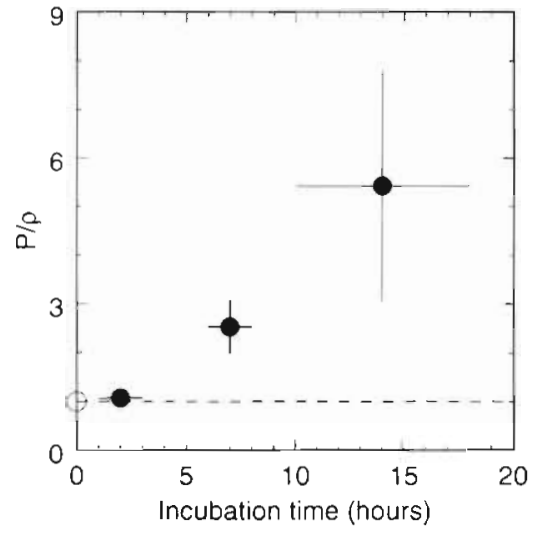

Fig. 4. Ratio between ammonium uptake rates corrected $(P)$ and uncorrected $(\rho)$ for isotope dilution as a function of incubation time. Horizontal lines indicate range in incubation times, while vertical lines are $\pm 1 \mathrm{SE} . P / \rho=1$ along the dashed line. The open symbol at $0 \mathrm{~h}$ has a $P / p$ value of 1 by definition. Samples numbers were: 1 to $3 \mathrm{~h}=25,6$ to $8 \mathrm{~h}=26$, 10 to $18 \mathrm{~h}=15$

cantly less than the percentage of missing label at 0 and $8 \mathrm{~m}$, but not statistically different from that missing at $12 \mathrm{~m}$. These data imply that our measured ammonium uptake rates may be underestimated, on average, by $36 \%$.

\section{Depth-dependent ammonium uptake and regeneration rates}

The highest daily ammonium uptake and regeneration rates generally occurred in the upper $12 \mathrm{~m}$ of the water column, although elevated regeneration rates were apparent periodically at $25 \mathrm{~m}$ (Fig. 5). Between 0 and $12 \mathrm{~m}$, peaks in ammonium uptake rates usually coincided with peaks in regeneration rates, especially during post-bloom conditions, such as on Day 219. Relatively low uptake and regeneration rates were measured during the onset of an active upwelling event on Day 555. In contrast to the surface waters,

Table 1. Percentage of ${ }^{15} \mathrm{~N}_{4}{ }^{+}$not recovered in the uptake and regeneration experiments for all time points at each depth. Mean $\pm \mathrm{SE}$

\begin{tabular}{|ccc|}
\hline $\begin{array}{c}\text { Depth } \\
(\mathrm{m})\end{array}$ & \% of ${ }^{15} \mathrm{~N}_{4}{ }^{+}$missing & $\mathrm{n}$ \\
\hline 0 & & \\
8 & $43.8 \pm 8.9$ & 9 \\
12 & $50.8 \pm 11.2$ & 8 \\
20 & $33.9 \pm 26.8$ & 2 \\
25 & 1.8 & 1 \\
$\bar{x} \pm \mathrm{SE}$ & $21.7 \pm 7.1$ & 8 \\
& $35.8 \pm 5.5$ & 28 \\
\hline
\end{tabular}




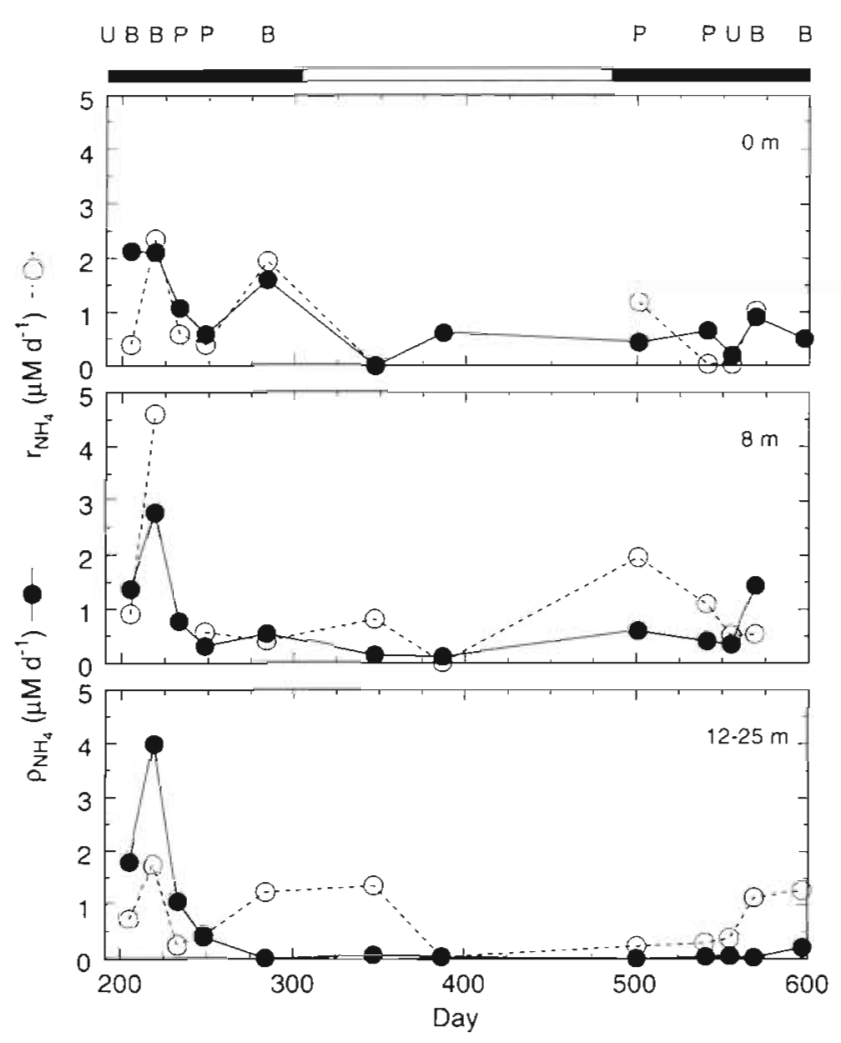

$|J| A|S| O|N| D|J| F|M| A|M| J|J| A \mid$

Fig. 5. Daily ammonium uptake (--) and regeneration $(-0-)$ rates at 0,8 , and 12 to $25 \mathrm{~m}$. The black bar indicates the duration of the upwelling season and the open bar the nonupwelling season. The upwelling status of each sampling period is shown by a letter: $\mathrm{U}=$ active upwelling, $\mathrm{B}=$ phytoplankton bloom, and $\mathrm{P}=$ post-bloom conditions

uptake rates at $25 \mathrm{~m}$ (Days 284 to 597) were always uniformly low, regardless of the stage in the upwelling cycle, and did not always correspond to changes observed in regeneration rates. Ammonium regeneration rates during the non-upwelling season were variable, ranging from being extremely low on Day 387 $\left(<0.01\right.$ to $\left.0.04 \mathrm{\mu M} \mathrm{d}^{-1}\right)$ to being similar to rates measured during the upwelling season $\left(0.8\right.$ to $\left.1.4 \mu \mathrm{M} \mathrm{d}^{-1}\right)$ on Day 347.

The fastest uptake and regeneration rates were found between 0 and $12 \mathrm{~m}$ during the upwelling season (Table 2). At this time of year uptake and regeneration rates were, on average, $\geq 0.9 \mu \mathrm{M} \mathrm{d}^{-1}$. Uptake rates decreased with depth during both the non-upwelling and the upwelling seasons, although it is interesting to note that at $25 \mathrm{~m}$ they were unchanged between seasons. Regeneration rates decreased with depth below $8 \mathrm{~m}$ during the upwelling season, but not as dramatically as observed in uptake rates. Nonupwelling regeneration rates at $8 \mathrm{~m}$ were about 4 -fold
Table 2. Comparison of daily ammonium uptake $(\rho)$ rates, regeneration $(r)$ rates, and regeneration: uptake $(r: \rho)$ ratios with depth during the upwelling and non-upwelling seasons. Sample numbers are in parentheses. Mean \pm SE. nd: no data

\begin{tabular}{|c|c|c|c|}
\hline $\begin{array}{c}\text { Depth } \\
\text { (m) }\end{array}$ & $\begin{array}{c}\rho_{\mathrm{NH}_{4}} \\
\left(\mu \mathrm{M} d^{-1}\right)\end{array}$ & $\begin{array}{c}r_{\mathrm{NH}_{1}} \\
\left(\mu \mathrm{M} \mathrm{d}^{-1}\right)\end{array}$ & $r: \rho$ \\
\hline \multicolumn{4}{|c|}{ Upwelling season } \\
\hline 0 & $1.02 \pm 0.22(10)$ & $0.89 \pm 0.28$ & $0.86 \pm 0.28 \quad$ (9) \\
\hline 8 & $0.95 \pm 0.27$ & $1.54 \pm 0.70(10)$ & $1.59 \pm 0.36$ \\
\hline 12 & $2.28 \pm 0.88$ & $0.86 \pm 0.14$ & $0.35 \pm 0.06$ \\
\hline 20 & 0.40 & 0.43 & 1.08 \\
\hline 25 & $0.07 \pm 0.04$ & $0.47 \pm 0.20$ & $34.10 \pm 18.76(6)$ \\
\hline \multicolumn{4}{|c|}{ Non-upwelling season: } \\
\hline 0 & $0.31 \pm 0.31$ & nd & nd \\
\hline 8 & $0.14 \pm 0.02$ & $0.41 \pm 0.41$ & $3.12 \pm 2.36$ \\
\hline 25 & $0.06 \pm 0.02$ & $0.70 \pm 0.66$ & $10.22 \pm 9.22$ \\
\hline
\end{tabular}

lower than rates measured during the upwelling season, while at $25 \mathrm{~m}$ these rates almost doubled.

Depth-dependent differences in uptake and regeneration rates were also reflected in $r: \rho$ ratios (i.e. regeneration:uptake) calculated from the daily rate data (Table 2). Mean net ammonium uptake occurred at 0 and $12 \mathrm{~m}$ during the upwelling season $(r: \rho<1)$, while at $20 m$ the 2 rates were essentially equal $(r: p \approx 1)$. Conversely, mean net ammonium regeneration $(r: \rho>1)$ was measured at 8 and $25 \mathrm{~m}$.

\section{Daily and seasonal ammonium uptake and regeneration rates}

Ammonium uptake and regeneration rates were generally balanced most of the time, when considering daily rates at specific depths (Fig. 5). The highest uptake $\left(4.0 \mu \mathrm{M} \mathrm{d}^{-1}\right)$ and regeneration rates $(4.6 \mu \mathrm{M}$ $\mathrm{d}^{-1}$ ) were measured on the same day (Day 219) but at different depths (12 and $8 \mathrm{~m}$, respectively). However, such high uptake and regeneration rates were quite uncommon. The majority of the uptake (25 of 35 ) and regeneration (20 of 32 ) rate data were $\leq 1 \mu \mathrm{M} \mathrm{d}^{-1}$.

Ammonium uptake and regeneration rates showed the same pattern with respect to stages in the upwelling cycle (Fig. 6). The fastest rates were measured during upwelling-induced phytoplankton blooms, intermediate rates characterized post-bloom conditions and the lowest rates coincided with an active upwelling event. Uptake rates at 0 and $8 \mathrm{~m}$ during the phytoplankton blooms were identical $(1.5 \mu \mathrm{M}$ $\mathrm{d}^{-1}$ ) and much higher than those at $25 \mathrm{~m}$ (Fig. 6A). Under bloom conditions, regeneration rates were similar at all depths (1.2 to $1.6 \mu \mathrm{M} \mathrm{d}^{-1}$ ) (Fig. 6B). Post-bloom events at 0 and $8 \mathrm{~m}$ were marked by 

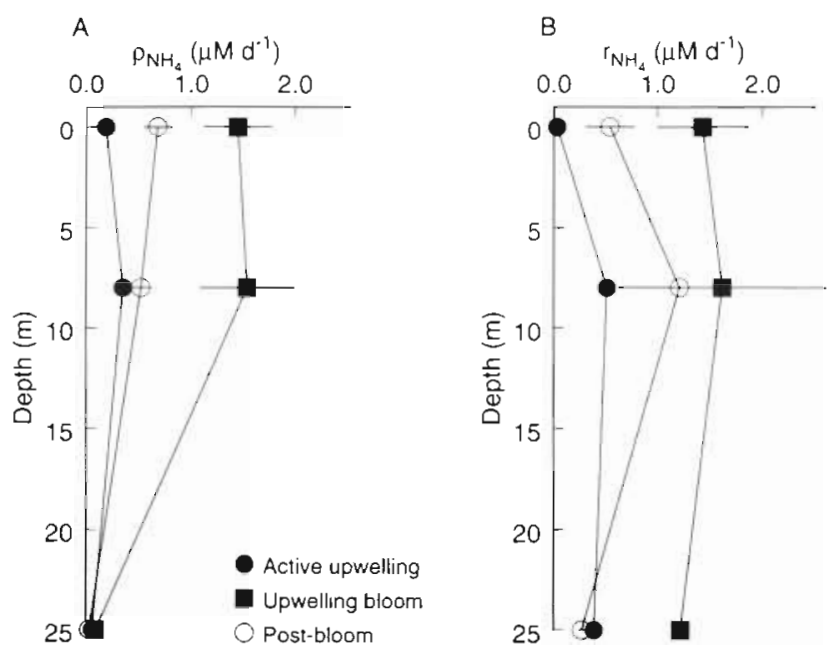

Fig. 6. Vertical profiles of (A) ammonium uptake $\left(\rho_{\mathrm{NH}_{4}}\right)$ and (B) regeneration $\left(r_{\mathrm{NH}_{4}}\right)$ rates at various stages in the upwelling cycle. Mean $\pm \mathrm{SE}$

slower uptake rates $\left(0.5\right.$ to $\left.0.7 \mu \mathrm{M} \mathrm{d}^{-1}\right)$. During such times regeneration rates at 0 and $25 \mathrm{~m}$ were $<1 \mu \mathrm{M}$ $\mathrm{d}^{-1}$, although rates at $8 \mathrm{~m}$ were not different from those during blooms. The lowest uptake and regeneration rates were found during an active upwelling event and were between $<0.1$ and $0.5 \mu \mathrm{M} \mathrm{d}^{-1}$

Mean depth-integrated ammonium uptake rates during the upwelling and non-upwelling seasons ranged from 3 to $17 \mathrm{mmol} \mathrm{N} \mathrm{m}^{-2} \mathrm{~d}^{-1}$ (Table 3). To test for statistical equality between the various mean uptake and regeneration rates, a $t$-test of the difference between 2 means was used (Sokal \& Rohlf 1981). Rates measured during the 2 upwelling seasons were not different from one another ( $p>0.05)$, but differed from the non-upwelling rate $(p \leq 0.05)$. Mean regeneration rates ( 13 to $20 \mathrm{mmol} \mathrm{m} \mathrm{m}^{-2} \mathrm{~d}^{-1}$ ) measured during the upwelling and non-upwelling seasons were not different from one another or from their paired uptake rate $(p>0.25)$. Using depth-integrated daily rates, annual ammonium uptake and regeneration rates were estimated to be $76.1 \pm 29.0 \mathrm{~g} \mathrm{~N} \mathrm{~m}^{-2} \mathrm{yr}^{-1}$ and $88.5 \pm 49.4 \mathrm{~g} \mathrm{~N} \mathrm{~m}^{-2} \mathrm{yr}^{-1}$, respectively. The annual ammonium uptake may be as high as $104 \mathrm{~g} \mathrm{~N} \mathrm{~m}^{-2} \mathrm{yr}^{-1}$ (correcting up by $36 \%$ ).

Table 3. Seasonal comparison of depth-integrated daily ammonium uptake $\left(\rho_{\mathrm{NH}_{4}}\right)$ and regeneration $\left(r_{\mathrm{NH}_{4}}\right)$ rates. Mean $\pm \mathrm{SE}$

\begin{tabular}{|lrcr|}
\hline Year/season & $\begin{array}{c}\rho_{\mathrm{NH}_{4}} \\
\left(\mathrm{mmol} \mathrm{N} \mathrm{m}^{-2} \mathrm{~d}^{-1}\right)\end{array}$ & $\begin{array}{c}r_{\mathrm{NH}_{4}} \\
\left(\mathrm{mmol} \mathrm{N} \mathrm{m}^{-2} \mathrm{~d}^{-1}\right)\end{array}$ & $\mathrm{n}$ \\
\hline 1990 upwelling & $17.2 \pm 4.5$ & $19.6 \pm 7.9$ & 5 \\
1990/91 non-upwelling & $3.4 \pm 0.9$ & $12.8 \pm 12.3$ & 2 \\
1991 upwelling & $10.8 \pm 2.8$ & $20.3 \pm 4.7$ & 5 \\
\hline
\end{tabular}

\section{DISCUSSION}

The time-dependence of ammonium uptake and regeneration rates has been reported by Glibert et al. (1982) and Harrison \& Harris (1986) for oceanic and coastal waters. In both studies the fastest ammonium uptake and regeneration rates coincided with the shortest incubation times and then the rates decreased with time. Glibert et al. (1982) suggested, but did not demonstrate, that initially fast rates reflected perturbation of the community due to confinement in an incubation bottle. Harrison \& Harris (1986) used the same argument to explain their results and speculated that handling and subsequent confinement of the community probably led to a loss of physiological vigor and increased levels of mortality. In this study the rate data were screened to remove any values that were compromised due to substrate depletion or decreases in the ${ }^{15} \mathrm{~N}$ enrichment of the PN. From our analysis of the ammonium uptake and regeneration time course experiments we found no evidence of time-dependence. Uptake and regeneration rates remained essentially constant for 10 to $18 \mathrm{~h}$ (Fig 2). For longer incubations rates may decrease with time, however, our results suggest that it becomes increasingly difficult to obtain valid rate measurements due to ammonium depletion and recycling of the ${ }^{15} \mathrm{~N}$ label.

Mass balance calculations indicated that more ${ }^{15} \mathrm{~N}$ was removed from the dissolved ammonium pool than was measured in the particulate fraction. Overall, we estimate that approximately $36 \%$ of the added ${ }^{15} \mathrm{~N}$ was not recovered. This value is similar to that reported by Kokkinakis (1987) for the Oregon/Washington coast ( $43 \%$ ) and to the $40 \%$ calculated by Laws (1984) for data collected in the Chesapeake Bay and Sargasso Sea by Glibert (1982). Laws (1984) suggested that such losses might arise from nitrification, adsorption of ammonium onto clay particles or the walls of the incubation bottles and/or the transformation of labelled ammonium and its subsequent release as dissolved organic nitrogen (DON). Assuming that bacteria primarily utilize DON and that bacterial production should be equivalent to DON production, Kokkinakis (1987) was able to show the rate at which ammonium was lost during incubations compared favourably with bacterial production rates measured by Wheeler \& Kirchman (1986) (i.e. $92 \mathrm{nM} \mathrm{h}^{-1}$ vs 0.2 to $178 \mathrm{nM} \mathrm{h}^{-1}$ ). More recently, Bronk et al. (1994) have reported that 21 to $35 \%$ of the ammonium and nitrate taken up by phytoplankton is released as DON. These data, as well as the fact that an increase in the atom $\%$ ${ }^{15} \mathrm{NH}_{4}{ }^{+}$of the dissolved pool was never observed coinciding with the loss of label from the particulate fraction (see Fig. 1), suggest that the ultimate fate of the missing label may have been into the DON pool and/or into heterotrophic bacteria (Wheeler \& Kirchman 1986). 
The net decrease in ammonium concentrations in $80 \%$ of our incubations implies that uptake rates exceeded regeneration rates. However, we found that regeneration rates were usually greater than or equal to uptake rates. This discrepancy can be attributed in part to our underestimation of uptake rates that is apparent from the mass balance comparisons described above. Conversely, it is also possible that regeneration rates were overestimated. Diel cycles in ammonium regeneration rates have been reported for the subarctic Pacific (Wheeler et al. 1989) and the Sargasso Sea (Glibert 1982). We were unable to measure regeneration rates over an entire diel cycle in this study but found no change in rates in incubations lasting up to $18 \mathrm{~h}$. Hence, we assumed that regeneration rates are constant for $24 \mathrm{~h}$ for our daily estimates. Clearly this assumption requires further testing, and our conclusions may need to be modified when additional information is available for this ecosystem. Despite the uncertainties in the rate estimates, 2 results support our interpretations of the daily, upwelling-related, and seasonal variations in rates. First, ambient ammonium concentrations remained within a narrow range (0.03 to $4.07 \mu \mathrm{M})$ and the ammonium pool turned over rapidly implying that there is a close balance between uptake and regeneration in situ. Second, we saw large coincident changes in rates for different stages of the upwelling cycle and for the comparison of upwelling and non-upwelling seasons. We believe that these changes must reflect large temporal variations in planktonic standing stocks.

The various stages of the upwelling cycle in the coastal waters off Oregon can be distinguished by changes in nutrient and biomass concentrations (Dickson \& Wheeler 1995). We observed large increases in both chl a and particulate nitrogen during upwelling-induced phytoplankton blooms and have documented the strong dependence of nitrate uptake rates on chl a standing stocks in these waters (Dickson \& Wheeler 1995). Similarly, Probyn (1987) has shown a strong relationship between particulate nitrogen concentrations and rates of ammonium regeneration in the Benguela upwelling system. In this study both ammonium uptake and regeneration rates were highest during the upwelling-induced blooms. Post-bloom rates were intermediate, and active upwelling rates were about an order of magnitude lower than rates meaured during the bloom. Estimated daily uptake and regeneration rates were similar for each part of the upwelling cycle with one exception. Regeneration of ammonium at $25 \mathrm{~m}$ during the upwelling blooms greatly exceeded uptake rates. We conclude that a significant amount of net regeneration occurs at depth during blooms. This may contribute to the ammonium plumes described below.
We expected to see large differences in ammonium uptake and regeneration rates when comparing upwelling and non-upwelling seasons. During both upwelling seasons ammonium uptake rates were lower than regeneration rates. However, when the uptake rates are corrected for the estimated loss of ${ }^{15} \mathrm{~N}$ to DON or uptake by heterotrophic bacteria, uptake and regeneration rates are closely balanced. Not surprisingly, uptake rates during the non-upwelling season were very low. In contrast, ammonium regeneration was high during one experiment and low during the other. The average regeneration rate for this period indicates net production of ammonium. However, a higher frequency of sampling during the nonupwelling season is needed to confirm this result. If there is net ammonium production during the nonupwelling season, it may be transported offshore during downwelling (Landry et al. 1989).

The dominance of various protist taxa and their grazing rates change seasonally at this site; nanoflagellates are numerically abundant during the upwelling season and ciliates are more common during the nonupwelling season (Neuer 1992). Wintertime grazing rates are between 0.00 and $0.16 \mathrm{~d}^{-1}$, compared to 0.18 and $0.50 \mathrm{~d}^{-1}$ during the upwelling season. The integrated regeneration data (Table 3 ) indicate that the rate at which organic nitrogen (i.e. particulate and/or dissolved) was transformed into ammonium was the same, regardless of the season. Since wintertime protist grazing rates are only a fraction of those during the upwelling season, our regeneration results suggest that bacteria or some other grazer assemblage may be more important in producing ammonium during the winter.

Macrozooplankton excretion rarely accounts for more than $30 \%$ of phytoplankton ammonium requirements (Bidigare 1983). On the Oregon/Washington shelf, macrozooplankton (i.e. copepod) excretion has been reported to contribute $<10 \%$ to phytoplankton ammonium requirements (Jawed 1973), although the data set was extremely limited. Although our regeneration data indicated the microbial community alone was able to meet phytoplankton ammonium requirements, there may be times when macrozooplankton excretion is enhanced. The presence of ammoniumladen water having concentrations of 2 to $4 \mu \mathrm{M}$ was found during post-bloom events when relaxed upwelling conditions prevailed (Dickson 1994) and coincided with depths where the greatest abundance of Pseudocalanus sp. occurs (Peterson et al. 1979). Results of a numerical model simulation of phytoplankton plume formation off Oregon predict the occurrence of high ambient ammonium concentrations after bloom events due to the leaching of macrozooplankton fecal pellets (Wroblewski 1977). From the net change in the 
uptake and regeneration rate data we estimate that it would have taken the microbial community between 2 and $85 \mathrm{~d}$ to establish such high ammonium concentrations. Whether microplankton were the sole source of this ammonium has yet to be determined.

Progress in understanding the dynamics of ammonium uptake and regeneration has been slow due to methodological problems. Isotope dilution techniques have improved the accuracy of uptake measurements and allowed determination of regeneration rates. Two additional problems need resolution. More direct measurement of DON release and bacterial uptake of ammonium are needed to verify the fate of 'missing $\mathrm{N}^{\prime}$ in ${ }^{15} \mathrm{~N}$ experiments. In addition the existence and causes of diel periodicity in regeneration rates need further investigation. Despite these limitations, our results show good balance between uptake and regeneration rates at most times during the upwelling season but with net ammonium production at depth during blooms. Finally, significant net regeneration of ammonium may occur during the non-upwelling season, though verification with a larger data set is clearly needed.

Acknowledgements. We thank the 3 anonymous reviewers of this paper for their constructive comments and suggestions. This research was supported by a NASA Graduate Student Fellowship in Global Change Research to M.L.D. and NSF grants OCE-9022403 and OCE-9101904 awarded to P.A.W.

\section{LITERATURE CITED}

Azam F, Fenchel T, Field JG, Gray JS, Meyer-Reil LA, Thingstad $F$ (1983) The ecological role of water-column microbes in the sea. Mar Ecol Prog Ser 10:257-263

Bidigare RR (1983) Nitrogen excretion by zooplankton. In: Carpenter EJ, Capone DG (eds) Nitrogen in the marine environment. Academic Press, New York, p 385-409

Blackburn TH (1979) Method for measuring rates of $\mathrm{NH}_{4}$ turnover in anoxic marine sediment, using a ${ }^{15} \mathrm{~N}-\mathrm{NH}_{4}$ dilution technique. Appl environ Microbiol 37:760-765

Bronk. D, Ward B, Glibert PM (1994) Nitrogen uptake, dissolved organic nitrogen release, and new production Science 265:1843-1846

Caperon J, Schell D, Hirota J, Laws E (1979) Ammonium excretion rates in Kaneohe Bay, Hawail, measured by a ${ }^{15} \mathrm{~N}$-isotope dilution technique. Mar Biol 54:33-40

Dickson ML (1994) Nitrogen dynamics in a coastal upwelling regime. PhD thesis, Oregon State University, Corvallis, p 227

Dickson ML, Wheeler PA (1995) Nitrate uptake rates in a coastal upwelling regime: a comparison of $\mathrm{PN}$-specific, absolute and chl a-specific rates. Limnol Oceanogr 40 (in press)

Dugdale RC, Goering JJ (1967) Uptake of new and regenerated forms of nitrogen in primary productivity. Limnol Oceanogr 12:196-206

Eppley RW, Peterson BJ (1979) Particulate organic matter flux and planktonic new production in the deep ocean. Nature 282:677-680
Fielder R, Proksch G (1975) The determination of nitrogen-15 by emission and mass spectrometry in biochemical analysis: a review. Analytica chim Acta $78: 1-62$

Glibert P (1982) Regional studies of daily, seasonal and size fraction variability in ammonium remineralization. Mar Biol 70:209-222

Glibert P, Lipschultz F, McCarthy JJ, Altabet MA (1982) Isotope dilution models of uptake and remineralization of ammonium by marine plankton. Limnol Oceanogr 27: $639-650$

Goldman JC, Caron DA, Dennett MR (1987) Regulation of gross growth efficiency and ammonium regeneration in bacteria by substrate $\mathrm{C}: \mathrm{N}$ ratio. Limnol Oceanogr 32 : $1239-1252$

Grasshoff K, Ehrhardt M, Kremling K (1983) Methods of seawater analysis. Verlag Chemie, Weinheim

Halpern D (1976) Structure of an upwelling event observed off Oregon during July 1973. Deep Sea Res 23:495-508

Harris E (1959) The nitrogen cycle in L.ong Island Sound. Bull Bingham oceanogr Coll 17:31-65

Harrison WG (1978) Experimental measurements of nitrogen remineralization in coastal waters. Limnol Oceanogr 23: $684-694$

Harrison WG (1980) Nutrient regeneration and primary production in the sea. In: Falkowski PG (ed) Primary productivity in the sea. Plenum Press, New York, p 433-460

Harrison WG (1992) Regeneration of nutrients. In: Falkowski PG, Woodhead AD (eds) Primary productivity and biogeochemical cycles in the sea. Plenum Press, New York, p 385-407

Harrison WG, Douglas D, Falkowski P, Rowe G, Vidal J (1983) Summer nutrient dynamics of the Middle Atlantic Bight: nitrogen uptake and regeneration. J Plankton Res 5 $539-555$

Harrison WG, Harris LR (1986) Isotope-dilution and its effect on measurements of nitrogen and phosphorus uptake by oceanic microplankton. Mar Ecol Prog Ser 27:253-261

Harrison WG, Head EJH, Conover RJ, Longhurst AR, Sameoto DD (1985) The distribution and metabolism of urea in the eastern Canadian Arctic. Deep Sea Res 32: $23-42$

Huyer A (1976) A comparison of upwelling events in two locations; Oregon and northwest Africa. J mar Res 34:531-546

Jawed M (1973) Ammonia excretion by zooplankton and its significance to primary production during summer. Mar Biol 23:115-120

Johannes RE (1964) Phosphorus excretion and body size in marine animals: microzooplankton and nutrient regeneration. Science 146:923-924

Kokkinakis SA (1987) Utilization of inorganic and organic nitrogen by phytoplankton off the Washington and Oregon coasts. MS thesis, Oregon State University, Corvallis, p 103

Kokkinakis SA, Wheeler PA (1988) Uptake of ammonium and urea in the northeast Pacific: comparison between netplankton and nanoplankton. Mar Ecol Prog Ser 43: $113-124$

Landry MR, Postel JR, Peterson WK, Newman J (1989) Broadscale distributional patterns of hydrographic variables on the Washington/Oregon shelf. In: Landry MR, Hickey BM (eds) Coastal oceanography of Washington and Oregon. Elsevier Science Publishers, Amsterdam, p 1-40

LaRoche J (1983) Ammonium regeneration: its contribution to phytoplankton nitrogen requirements in a eutrophic environment. Mar Biol 75:231-240

Laws $E$ (1984) Isotope dilution models and the mystery of the vanishing ${ }^{i 5} \mathrm{~N}$. Limnol Oceanogr 29:379-385 
Menzel DW (1967) Particulate organic carbon in the deep sea. Deep Sea Res 14:229-238

Neuer S (1992) Role of protist grazing in the Oregon upwelling system. PhD thesis, Oregon State University, Corvallis, $p 172$

Paasche E, Kristiansen S (1982) Ammonium regeneration by microzooplankton in the Oslofjord. Mar Biol 69:55-63

Peterson WT, Miller CB, Hutchinson A (1979) Zonation and maintenance of copepod populations in the Oregon upwelling zone. Deep Sea Res 26:467-494

Press WH, Flannery BP, Teukolsky SA, Vetterling WT (1989) Numerical recipes, 1st edn. Cambridge University Press, Cambridge

Price NM, Cochlan WP, Harrison PJ (1985) Time course of uptake of inorganic and organic nitrogen by phytoplankton in the Strait of Georgia: comparison of frontal and stratified communities. Mar Ecol Prog Ser 22:39-53

Probyn TA (1987) Ammonium regeneration by microplankton in an upwelling environment. Mar Ecol Prog Ser 37:53-64

Selmer JS, Sörensson F (1986) New procedure for extraction of ammonium from natural waters for ${ }^{15} \mathrm{~N}$ isotopic ratio determinations. Appl environ Microbiol 52:577-579

Small LF, Menzies DW (1981) Patterns of primary productivity

This article was submitted to the editor and biomass in a coastal upwelling region. Deep Sea Res 28A:123-149

Sokal RR, Rohlf FJ (1981) Biometry, 2nd edn. WH Freeman and Co, San Francisco

Solórzano L (1969) Determination of ammonium in natural waters by the phenolhypochlorite method. Limnol Oceanogr 14:799-801

Wheeler PA, Kirchman DL (1986) Utilization of inorganic and organic forms of nitrogen by bacteria in marine systems. Limnol Oceanogr 31:998-1009

Wheeler PA, Kirchman DL, Landry MR, Kokkinakis SA (1989) Diel periodicity in ammonium uptake and regeneration in the oceanic subarctic Pacific: implications for interactions in microbial foodwebs. Limnol Oceanogr 34:1025-1033

Wheeler PA, Kokkinakis SA (1990) Ammonium recycling limits nitrate use in the oceanic subarctic Pacific. Limnol Oceanogr 35:1267-1278

Whitledge TE, Veidt DM, Malloy SC, Patton CJ, Wirick CD (1986) Automated nutrient analyses in seawater. Brookhaven Nat Lab Tech Rept, BNL 38990

Wroblewski JS (1977) A model of phytoplankton plume formation during variable Oregon upwelling. J mar Res $35: 357-394$

Manuscript first received: July 8,1994

Revised version accepted: December 27, 1994 